\title{
Fertile Derivatives from Sparkleberry $\times$ Blueberry Crosses
}

\author{
P.M. Lyrene \\ Fruit Crops Department, University of Florida, 1137 Fifield Hall, Gainesville, FL 32611 \\ Additional index words. Vaccinium arboreum, Vaccinium darrowi, wide hybridization, blueberry breeding
}

Abstract. Diploid plants in Vaccinium section Cyanococcus, including plants of V. darrowi Camp, V. atrococcum Heller (diploid V.corymbosum L.), a V.atrococcum $\times$ V.darrowi $F_{1}$ hybrid, and a V.atrococcum $\times$ V. elliottii $\mathbf{C h a p m n}$. $F_{1}$ hybrid, were hand pollinated in a greenhouse with pollen from diploid V. arboreum Marsh. (Section Batodendron). The resulting seeds were germinated and the seedlings were transplanted to a high-density field nursery. Forty of these $F_{1}$ intersectional hybrids were selected after 2 1/2 years and transplanted to a $1.5 \times 4-m$ spacing. Most of these plants were vigorous and flowered heavily in subsequent years, but only a small percentage of the flowers produced fruit. In 1990, however, $>4000$ berries were harvested from the 35 surviving plants. Open-pollinated seed from a much smaller number of berries was planted in Dec. 1987; these seeds produced $\approx 200$ seedlings, some of which had moderate to high fruit set in a field nursery in 1989. Six of these seedlings, which were selected for high vigor, high fruit set, and characteristics intermediate between section Cyanococcus and section Batodendron, had fruit set ranging from $19.4 \%$ to $92.7 \%$ when pollinated with pollen from tetraploid V. corymbosum cultivars. One of the six seedlings was highly self-fruitful, and some intercrosses among the six seedlings produced much viable seed. Large-scale introgression of $\mathrm{V}$. arboreum genes into tetraploid highbush cultivars likely will be possible by the methods used in this study.

The cultivated blueberries of eastern North America, highbush (Vaccinium corymbosum L.), lowbush (V. angustifolium Ait .), and rabbiteye (V. ashei Reade), are in Vaccinium section Cyanococcus. Two widespread Vaccinium spp. native to the southeastern United States, the deerberry. (V. stamineum L.) and the sparkleberry (V. arboreum Marsh.), are in sections Polycodium and Batodendron, respectively.

Except for the cultivar Aron (Hiirsalmi and Lehmushovi, 1982), which was developed in Finland from V. corymbosum (section Cyanococcus) $\times$ V. uliginosum $L$. (section Vaccinium) crosses, no blueberry cultivars are known to have genes from species outside of Vaccinium section Cyanococcus. In addition to the $\mathrm{V}$. corymbosum $\times \mathrm{V}$. uliginosum hybrids that gave rise to the cultivar Aron, other intersectional hybrids involving section Cyanococcus have included Cyanococcus-Polycodium, Cyanococcus-Herpothamnus, and Cyanococcus-Batodendron (Lyrene and Ballington, 1986).

The sparkleberry is a small tree, sometimes reaching $10 \mathrm{~m}$ in height with a trunk up to $35 \mathrm{~cm}$ diameter at breast height (Camp, 1945; Vander Kloet, 1988). Its range extends from southern Virginia to central Florida, west to eastern Texas, central Oklahoma, and southeastern Missouri (Vander Kloet, 1988). Although sparkleberry is sometimes used in landscaping, its fruit, which ripen in the fall and are dark, somewhat astringent, and "gritty," are not normally consumed by humans.

The sparkleberry has several characteristics that would be useful in blueberry cultivars. Wild sparkleberry plants often grow on soils that are too dry, too low in organic matter, or too high in $\mathrm{pH}$ to allow growth of $V$. corymbosum. This adaptation suggests that sparkleberry could be a source of genes from broader soil tolerance. Sparkleberry flowers have shorter corolla tubes and wider corolla openings than blueberry flowers, and flowers of some sparkleberry clones are more fragrant than blueberry flowers. If these sparkleberry flower characteristics could be incorporated into blueberry cultivars, they might result in better

Received for publication 22 Oct. 1990. Florida Agricultural Experiment Station Journal Series no. R-O111O. The cost of publishing this paper was defrayed in part by the payment of page charges. Under postal regulations, this paper therefore must be hereby marked advertisement solely to indicate this fact. insect pollination and improved fruit set. The late flowering of the sparkleberry makes it less subject to crop loss due to freezes than cultivated blueberries.

The purpose of this report is to describe a method that has been used to obtain fertile blueberry $\times$ sparkleberry hybrid derivatives that can be crossed readily with tetraploid highbush blueberry cultivars.

\section{Materials and Methods}

Two V. darrowi plants (cv. Johnblue and FL 80-61) and an intrasectional Cyanococcus hybrid (diploid Florida native V. corymbosum $\times \mathrm{V}$. darrowi) were dug from a field nursery in Dec. 1980, potted, and placed in a dark cooler at $\approx 5 \mathrm{C}$. These plants were moved to a greenhouse in Feb. and Mar. 1981 as sparkleberry pollen became available. Sparkleberry normally flowers later in the spring than the blueberries used as seed parents. This problem was overcome by holding the blueberry plants in a cooler and searching large populations of sparkleberry for off-season and early season flowering. The sparkleberry plants used in the crosses came from Alachua County (five plants) and Santa Rosa County (one plant), both of which are in north Florida. Flowering branches were cut from the sparkleberry plants and placed in water jugs in a greenhouse to serve as a pollen source. The blueberry plants used as seed parents were emasculated before anthesis and pollinated immediately with sparkleberry pollen taken from the flowering branches. The resulting seeds were sown in Nov. 1981 on peat under intermittent mist, and the seedlings were transplanted in May 1982 to a high-density field nursery. After the plants had been in the field for $21 / 2$ years, 19 that had high vigor and clearly showed characteristics that were intermediate between the parent species were transplanted to a $1.5 \times 4-\mathrm{m}$ spacing in Dec. 1984. Sixteen plants that were still alive in July 1990 were evaluated (Table 1).

Twenty-one additional Cyanococcus diploid $\times$ V. arboreum $\mathrm{F}_{1}$ hybrids were produced from crosses made in 1982. These were selected in a high-density nursery in Fall 1985 and were transplanted to a $1.5 \times 4-\mathrm{m}$ spacing in Dec. 1985. In this second set of crosses, one seed parent was a native diploid V. corymbosum from Alachua County, and the other was a diploid 
Table 1. Characteristics of plants of 16 eight-year-old $\mathrm{d}^{\mathrm{z}}$ Cyanococcus $\times V$. arboreum $\mathrm{F}_{1}$ hybrids open-pollinated in 1990 at the blueberry research farm in Gainesville, Fla.

\begin{tabular}{|c|c|c|c|c|c|c|}
\hline \multirow[b]{2}{*}{ Plant } & \multicolumn{2}{|c|}{ Parents } & \multirow[b]{2}{*}{$\begin{array}{c}\mathrm{Ht} \\
(\mathrm{cm})\end{array}$} & \multirow[b]{2}{*}{$\begin{array}{l}\text { Diameter }^{y} \\
(\mathrm{~cm})\end{array}$} & \multirow{2}{*}{$\begin{array}{c}\text { Berries } \\
\text { harvested } \\
\text { (no.) }\end{array}$} & \multirow{2}{*}{$\begin{array}{c}\text { Total seed } \\
\text { wt } \\
(\mathrm{g})\end{array}$} \\
\hline & $\begin{array}{l}\text { Cyanococcus } \\
\text { (seed parent) }\end{array}$ & $\begin{array}{l}V . \text { arboreum } \\
\text { (pollen parent) }\end{array}$ & & & & \\
\hline FL $85-125$ & FL80-98 & FL81-79w & 115 & 120 & 185 & 0.25 \\
\hline-126 & & & 240 & 150 & 10 & $<0.10$ \\
\hline-127 & & & 140 & 150 & 480 & 1.31 \\
\hline-136 & & & 190 & 140 & 0 & 0 \\
\hline-137 & & & 155 & 90 & 0 & 0 \\
\hline-138 & & & 170 & 235 & 5 & $<0.10$ \\
\hline-139 & " & & 155 & 195 & 0 & 0 \\
\hline Mean & & & 166 & 154 & & \\
\hline SD & & & 40.0 & 47.8 & & \\
\hline FL $85-128$ & V. darrowi-FL80-61 & FL $82-29^{4}$ & 100 & 80 & 0 & 0 \\
\hline-129 & & & 130 & 75 & 20 & $<0.10$ \\
\hline-141 & & & 195 & 260 & 0 & 0 \\
\hline Mean & & & 142 & 138 & & \\
\hline SD & & & 48.6 & 105.4 & & \\
\hline FL $85-130$ & $V$. darrowi cv. Johnblue & FL 82-29u & 205 & 185 & 360 & 1.41 \\
\hline-131 & & & 250 & 285 & 2610 & 8.41 \\
\hline-132 & & & 250 & 210 & 0 & 0 \\
\hline-133 & & & 160 & 155 & 5 & $<0.10$ \\
\hline-134 & & & 190 & 215 & 585 & 0.92 \\
\hline-135 & & & 180 & 170 & 0 & 0 \\
\hline Mean & & & 206 & 203 & & \\
\hline SD & & v & 37.2 & 46.1 & & \\
\hline
\end{tabular}

${ }^{2}$ Plants were from crosses made in 1981, were 7.5 years old from seed, and had been transplanted to their permanent fieid location 5.5 years before measurements were made.

${ }^{y}$ Canopy diameter: average of east-west measurement with north-south measurement.

${ }^{x}$ Diploid hybrid between diploid V. corymbosum ( $V$. atrococcum phase) native in Alachua County, Fla., and V. darrowi from central Florida peninsula.

"From Yellow River southeast of Milton in western Florida (Santa Rosa County).

${ }^{v} \mathrm{~V}$. darrowi from central Florida peninsula.

"V. arboreum from Gainesville, Fla. (Alachua County).

V. corymbosum $x$ V. elliottii $\mathrm{F}_{1}$ hybrid. The four $\mathrm{V}$. arboreum plants used were from Alachua County.

Low fertility, as evidenced by low fruit set after open pollination in the presence of a wide variety of Vaccinium pollen sources available at the blueberry research farm, made controlled crosses involving the $\mathrm{F}_{1}$ plants appear unprofitable. However, as the plants grew older, some became highly floriferous, and several began to produce a few berries containing viable seeds. Beginning in 1987, open-pollinated seed was collected yearly from the $F_{1}$ plants and sown in the greenhouse.

The first seedling population from open-pollination of the Cyanococcus $\times \mathrm{V}$. arboreum $\mathrm{F}_{1}$ hybrids consisted of 200 plants that were transplanted to a high-density field nursery in May 1988. These came from five $\mathrm{F}_{1}$ plants. Forty additional openpollinated seedlings from the same seed parents were transplanted to the field nursery in 1989 and 160 more in 1990.

The first seedling lot was evaluated during the 1989 growing season. Six plants that clearly showed both V. arboreum and Cyanococcus traits were selected based on high vigor, aboveaverage fruit set, and above-average fruit size for the population. These were dug and potted in Dec. 1989 and placed in a dark cooler at $5 \mathrm{C}$ for 30 days before being moved to a beeproof greenhouse for crossing. Three types of pollinations were made using these plants as seed parents: self-pollination, pollination with pollen from cultivated tetraploid highbush cultivars, and interpollinations among the six seed parents.

The first 20 berries that ripened from each pollination type on each plant were weighed. Seeds were extracted from all berries obtained from each cross by use of Waring Blender, and seeds that did not float in water were rinsed, dried, and weighed. These seeds were planted in Nov. 1990 on peat under intermittent mist in a greenhouse, and seedlings that were alive on 20 Feb. 1991 were counted.

\section{Results and Discussion}

V. darrowi $\times \mathrm{V}$. arboreum $\mathrm{F}_{1}$ hybrids were not difficult to obtain. Both parents are diploid, and although the success rate of the crosses in terms of seedlings per pollinated flower was low compared with typical homoploid crosses within Vaccinium Section Cyanococcus (data not shown), it was equal to or higher than normal success rates in tetraploid $\times$ diploid crosses within Cyanococcus (e.g., tetraploid V. corymbosum $\times$ diploid V. corymbosum, V. darrowi, or $V$. elliottii). The crossing rate varied greatly depending on which V. darrowi and V. arboreum clones were used. Some combinations gave no viable seed after $\geq 500$ flowers had been pollinated. Many of the $F_{1}$ plants were vigorous. Of 40 selected plants transplanted to $1.5 \times 4 \mathrm{~m}$ spacing in 1984 and 1985, only six had died by 1990. The average height in 1990 of surviving plants was $176 \mathrm{~cm}$ for those transplanted in Dec. 1984 and $150 \mathrm{~cm}$ for those transplanted in Dec. 1985. Average canopy diameters were $170 \mathrm{~cm}$ for the 1984 transplants and $142 \mathrm{~cm}$ for the 1985 transplants.

Many morphological characteristics of the $F_{1}$ plants were intermediate between the parental species, including leaf size, shape, and degree of deciduousness. Bark, inflorescence, and flower morphology were also intermediate. $F_{1}$ seedlings were 


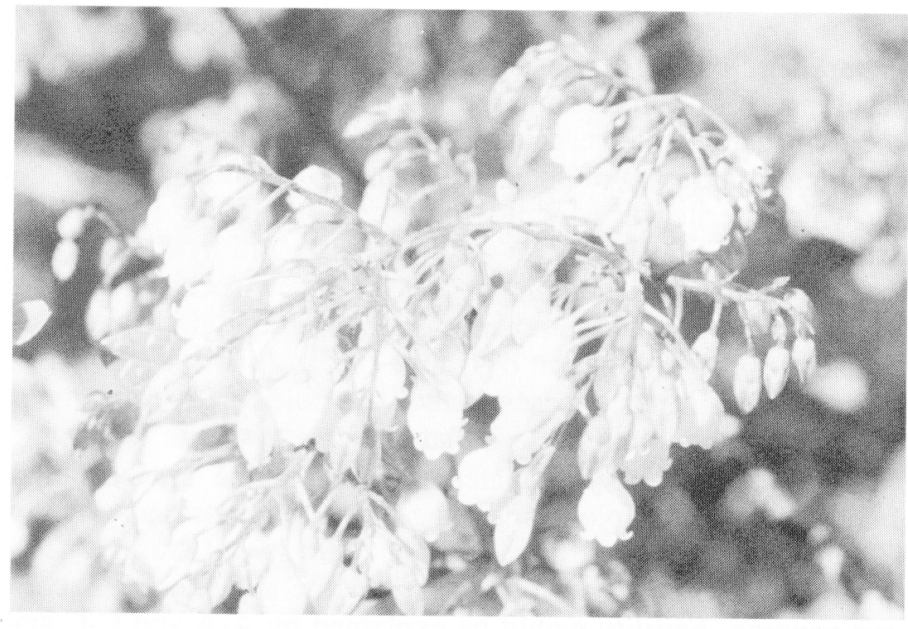

Fig. 1. Flowering branch on $V$. darrowi $\times V$. arboreum $\mathrm{F}_{1}$ hybrid. Long peduncles and pedicels are characteristic of $V$. arboreum.

highly variable within crosses; this can be explained by the heterozygosity of the parental clones.

Fertility of the $F_{1}$ hybrids was low after open pollination in a row surrounded by Vaccinium section Cyanococcus plants of several species and three ploidy levels $(2 \mathrm{x}, 4 \mathrm{x}, 6 \mathrm{x})$. Flowering was extremely abundant on some plants, and all or nearly all plants flowered to some extent (Fig. 1). Berries were harvested in 1988, 1989, and 1990. In 1990, the four most fruitful plants yielded 2610, 585, 480, and 360 berries, respectively (Table 1). Total fruit yield for the $F_{1}$ population was far higher in 1990 than in either of the two preceding years. In part, this difference reflects freeze losses in 1988 and 1989 and increased flowering as the plants grew older and larger. In addition, fruit set appeared to be improving with plant age. Fruit size was quite small, averaging from 0.15 to $0.29 \mathrm{~g} /$ berry for five fruiting plants. This small size is partly a consequence of low seed count per fruit.

The fruitfulness of $F_{1}$ seedlings varied greatly from cross to cross. Seedlings from the cross $\boldsymbol{V}$. darrowi 'Johnblue' $\times V$. arboreum FL 82-29 were the most fruitful. The two populations in which the seed parents were not $\boldsymbol{V}$. darrowi or $\boldsymbol{V}$. darrowi hybrids produced no fruit with seed (data not shown), even though the 19 plants in these crosses were generally vigorous and flowered to some extent, although less than the $\boldsymbol{V}$. darrowi hybrids.

The origin of the pollen that caused viable seed to form on the $\mathrm{F}_{1}$ intersectional hybrids is not known. The primary flowering season of the $F_{1}$ hybrids was later than that of the rabbiteye and highbush clones that were potential pollen sources in the test field. Some high-chill North Carolina tetraploid highbush clones, whose flowering was delayed by insufficient chilling, were flowering in the adjacent row. A few rabbiteye (6x) flowers were still available within $100 \mathrm{~m}$. However, most of the readily available flowers were on the $F_{1}$ plants themselves, but low pollen fertility undoubtedly reduced the extent of intercrossing.

Seedlings resulting from open-pollination of the $F_{1}$ plants were highly variable. About half had medium to high fertility after open pollination in their first year of fruiting. Mean fruit size for the open-pollinated seedings ranged from $0.3 \mathrm{~g}$ to $1.6 \mathrm{~g}$. On some plants, the fruit were quite seedy, indicting high female fertility. Although the fruit were dark, berries of some seedlings were slightly glaucous. Some of the seedlings bore fruit on long pedicels, a characteristic of V. arboreum.

Fruit set in the six open-pollinated selections, after they were hand-pollinated in the greenhouse, ranged from $17.4 \%$ to $92.7 \%$ (Table 2). The flowers on these plants were far larger than those on their $\mathrm{F}_{1}$ parents (Fig. 2), which strongly suggests an increase in ploidy. Further indications that the six open-pollinated selections were tetraploid were their high fertility after open-pollination relative to their $F_{1}$ parents, the great increase in fruit size compared with the $F_{1}$ parents, and their relatively high fruit set and seed yield after pollination with pollen from tetraploid highbush cultivars in the greenhouse.

The three types of crosses made in the greenhouse using five of the six selected open-pollinated seedlings as seed parents (pollination with tetraploid highbush pollen, self-pollination, and intercrosses among the six) gave rather similar percent fruit set when compared for particular seed parents (rows in Table 3). Self-pollination resulted in lower seed yields than cross-pollination. Neither fruit size nor ripening date differed markedly for self-pollination compared with cross-pollination (data not

Table 2. Fertility characteristics in crosses involving open-pollinated seedlings from Cyanococcus $\times$ V. arboreum crosses.

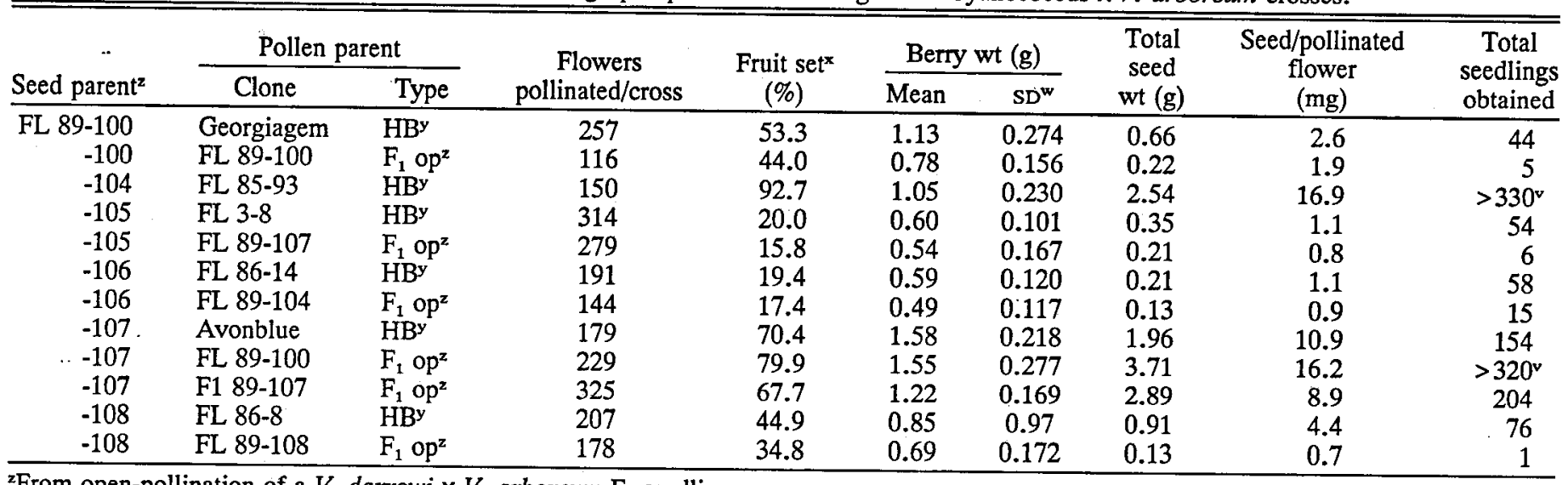

${ }^{z}$ From open-pollination of a $V$. darrowi $\times V$. arboreum $\mathrm{F}_{1}$ seedling.

yetraploid highbush cultivar.

"Number of ripe fruit $\div$ number of pollinated flowers.

"To get standard errors, divide by 4.47 .

veedlings were so crowded in the pot that some seed had poor germination conditions. 


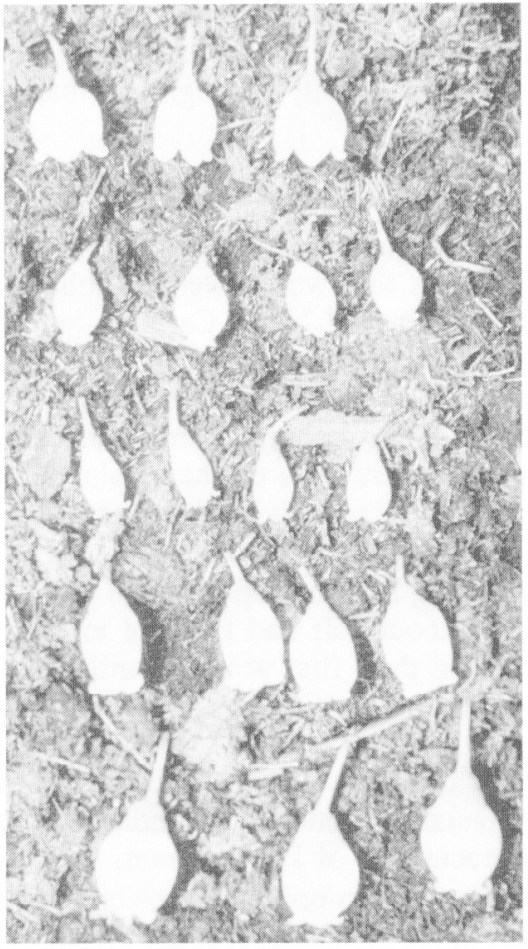

Fig. 2. Flowers of $V$. arboreum (top row), $V$. darrowi (second row), a typical $F_{1}$ hybrid (third row), and of two open-pollinated seedlings of the $F_{1}$ hybrid (bottom two rows). The increase in flower size in the O.P. seedlings over the $F_{1}$ hybrid is evidence for a doubled chromosome number.

Table 3. Percent fruit set and seed yield per pollinated flower for five intersectional-hybrid seedlings hand-pollinated in a greenhouse with three classes of pollen.

\begin{tabular}{|c|c|c|c|}
\hline \multirow[b]{2}{*}{ Seed parent ${ }^{2}$} & \multicolumn{3}{|c|}{ Pollen source } \\
\hline & Highbush & F, o.p. & Selfed \\
\hline \multicolumn{4}{|c|}{ Fruit set $(\%)$} \\
\hline $89-100$ & 53.3 & $---y$ & 44.0 \\
\hline-105 & 20.0 & 15.8 &.$--y$ \\
\hline-106 & 19.4 & 17.4 & $---y$ \\
\hline-107 & 70.4 & 79.9 & 67.7 \\
\hline-108 & 44.9 & $--^{y}$ & 34.8 \\
\hline \multicolumn{4}{|c|}{ Seed yield/pollinated flower $(\mathrm{mg})$} \\
\hline $89-100$ & 2.6 & $---y$ & 1.9 \\
\hline-105 & 1.1 & 0.8 & $--y$ \\
\hline-106 & 1.1 & 0.9 & $\ldots y$ \\
\hline-107 & 10.9 & 16.2 & 8.9 \\
\hline-108 & 4.4 & $\ldots y$ & 0.7 \\
\hline
\end{tabular}

${ }^{{ }^{2}}$ Seed parents were all seedlings obtained by open-pollination of $F_{1}$ Cyanococcus $\times V$. arboreum hybrids. These five were selected from a population of $\approx 200$ for high fruit set after open-pollination in the field. yCross not attempted.

shown). Only. FL $89-107$ produced many seedlings after selfpollination (Table 2). Most of the seedlings from the crosses listed in Table 2 appeared to be vigorous in the seedling trays, but some crosses produced many chlorotic seedlings.
The low fertility of the $F_{1}$ plants from Cyanococcus $\times \mathrm{V}$. arboreum crosses is probably due to poor chromosome pairing resulting from chromosome structural differentiation between the two sections of the genus. Chromosome number doubling, resulting from fusion of unreduced gametes, is a common method by which sterile wide hybrids give rise to tetraploid offspring with increased fertility. The resulting tetraploid hybrids, called amphidiploids, can sometimes give rise to new species. Clausen et al. (1945) produced numerous fertile tetraploids in the Madiinae by open-pollination of nearly sterile diploid $\mathrm{F}_{1}$ interspecific hybrids. In some cases, they were able to experimentally recreate amphidiploid species that already existed in nature.

If our fertile open-pollinated progeny of the intersectional hybrids are amphidiploids resulting from intercrosses among the $F_{1}$ plants, they would have the genomic constitution AACC, where A represents a V. arboreum genome and $\mathrm{C}$ a Cyanococcus genome. Fertility would be explained by A-A and C-C autosyndetic pairing. Crosses of these tetraploids with tetraploid V. corymbosum (CCCC) should give seedlings with a genomic formula ACCC. These could have reduced fertility due to poor pairing between the $\mathrm{A}$ and $\mathrm{C}$ genomes. However, intercrosses among amphidiploids (AACC $\times$ AACC) would be expected to yield fertile progeny. Thus, information on the genomic composition of the open-pollinated seedlings may be obtained by comparing the fertility of the seedlings from the three types of crosses made in the greenhouse.

An alternative to amphidiploidy as an explanation for the origin of the fertile, open-pollinated progeny from the diploid sterile hybrids is fusion of unreduced eggs from the $F_{1}$ hybrid with reduced pollen from tetraploid $\mathrm{V}$. corymbosum. The resulting genomic formula for the seedlings under this hypothesis would be CCCA, where $\mathrm{C}$ represents section Cyanococcus genomes and $\mathrm{A}$ the $\mathrm{V}$. arboreum genome. Poor pairing between homoeologous chromosomes of the $\mathrm{A}$ and $\mathrm{C}$ genomes would be expected to reduce the fertility of plants of this type, but polyploidy might minimize the reduction in fertility.

These studies indicate that vigorous plants with medium to high fruitfulness can be obtained in early generations following crosses between V. darrowi and V. arboreum. V. arboreum may prove useful in breeding blueberry cultivars because it is so abundant and widespread, and because many of its vegetative characteristics seem superior to those of the Cyanococcus species with respect to commercial cultivation.

\section{Literature Cited}

Camp, W.H. 1945. The North American blueberries with notes on other groups of Vacciniaceae. Brittonia 5:203-275.

Clausen, J. D., D. Kech, and W.M. Hiesey. 1945. Experimental studies on the nature of species. II Plant evolution through amphidiploidy and autoploidy, with examples from the Madiinae. Carnegie Inst. of Washington Pub. no. 564.

Hiirsalmi, H. and A. Lehmushovi. 1982. A Finnish highbush blueberry variety 'Aron'. Ann. Agr. Fenniae 21:151-154.

Lyrene, P.M. and J.R. Ballington. 1986. Wide hybridization in Vaccinium. HortScience 21:52-57.

Vander Kloet, S.P. 1988. The genus Vaccinium in North America. Pub. 1828, Can. Govt. Pub. Ctr., Ottawa. 